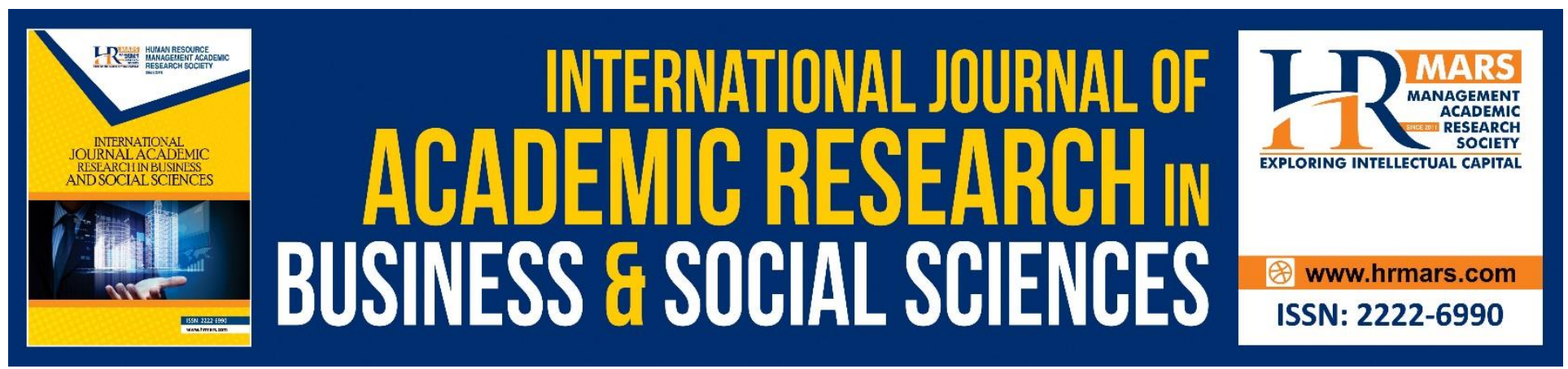

\title{
Preliminary Investigation: Accounting Literacy among Small Business Owners
}

Nurfarahin Roslan, Nur Farahah Mohd Pauzi, Khairiah Ahmad, Adriana Shamsudin, Mohd Syazwan Karim, Sharifah Norhafiza Syed Ibrahim

To Link this Article: http://dx.doi.org/10.6007/IJARBSS/v8-i10/4709

DOI: $10.6007 /$ IJARBSS/v8-i10/4709

Received: 03 Sept 2018, Revised: 19 Oct 2018, Accepted: 21 Oct 2018

Published Online: 28 October 2018

In-Text Citation: (Roslan et al., 2018)

To Cite this Article: Roslan, N., Pauzi, N. F. M., Ahmad, K., Shamsudin, A., Karim, M. S., \& Ibrahim, S. N. S. (2018). Preliminary Investigation: Accounting Literacy among Small Business Owners. International Journal of Academic Research in Business and Social Sciences, 8(10), 32-47.

Copyright: (c) 2018 The Author(s)

Published by Human Resource Management Academic Research Society (www.hrmars.com)

This article is published under the Creative Commons Attribution (CC BY 4.0) license. Anyone may reproduce, distribute, translate and create derivative works of this article (for both commercial and non-commercial purposes), subject to full attribution to the original publication and authors. The full terms of this license may be seen

at: http://creativecommons.org/licences/by/4.0/legalcode

Vol. 8, No. 10, 2018, Pg. 32 - 47

Full Terms \& Conditions of access and use can be found at http://hrmars.com/index.php/pages/detail/publication-ethics 


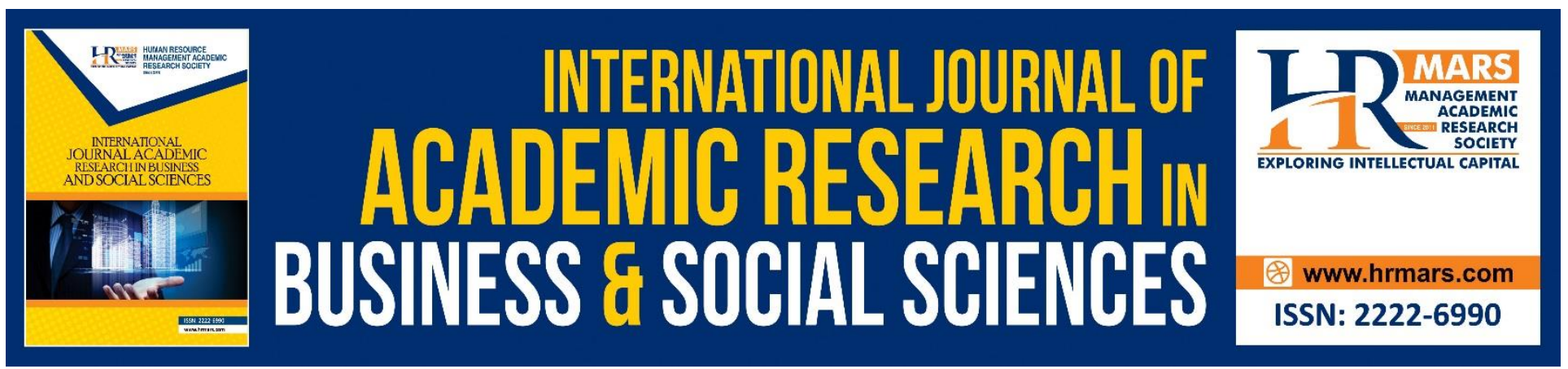

\title{
Preliminary Investigation: Accounting Literacy among Small Business Owners
}

\author{
Nurfarahin Roslan, Nur Farahah Mohd Pauzi, Khairiah Ahmad, \\ Adriana Shamsudin, Mohd Syazwan Karim, Sharifah Norhafiza Syed \\ Ibrahim
}

Faculty of Accountancy, Universiti Teknologi MARA, Melaka, Malaysia

\begin{abstract}
Accounting is important for a business of any sizes to keep well-organized and up-to-date accounting records for their daily transactions. It helps businesses to plan and manage financial matters more effectively. However, most of the small business owners do not keep proper books of accounts since there is no legal obligation to do that. Moreover, they also perceive accounting as a very difficult process due to its technical difficulties. Thus, it is quite hard for the small business owners to monitor the financial status/growth and also obtaining financial assistance from third parties. Hence, this study examines the extent of accounting literacy which focuses on accounting records and financial management among small business owners in Jasin district. 51 small business owners responded to the questionnaire distributed. Findings of this study revealed that, in terms of accounting records, majority of the small business owners do not have proper record keeping and do not concern on separation of business and personal transactions. Besides, almost $70 \%$ of them did not maintain any financial reports for the business. In terms of financial management, most of the owners use selffinancing in running the business since they are worried they cannot afford the loan commitments. Apart from that, it might be difficult for them to apply for a loan due to no proper business record and financial reports prepared for the business. These results indicate that accounting literacy is still very weak among the small business owners in Jasin district.
\end{abstract}

Keywords: Accounting literacy, Small Medium Entities (SMEs), Records and Financial Management, Growth

\section{Introduction}

Accounting literacy especially record keeping is important since it played a key role in the success and failure of a business. Record keeping is a fundamental skill a business owner must have as the accounting information is vital for decision making. Accounting knowledge is essential to all type of businesses in order to plan and manage financial matters effectively. Recording and reporting daily business transactions by using accounting techniques helps owners to identify cash flow, cost of 
production, assets and liabilities (Umeji \& Obi, 2014). Apart from that, accounting information is important for external parties such as bankers and creditors in order to make decision on giving out loan and also to potential investors to make evaluation for investment. Given the importance of accounting, it is yet to be utilized by the small business owners in reporting their transactions since they have no obligation to keep proper books of accounts. To date, Small and Medium Enterprise (SMEs) play an important role in contributing to the national economy. SMEs in Indonesia influence about $91.8 \%$ of Indonesia's economy (Kurniawati, Kurniawan, \& Kristiani, 2013). A study conducted by (Coda, Viveiros, Krakauer, \& Franc, 2018) discovered more than ten million micro and small entrepreneurs who contributes $27 \%$ in gross domestic product (GDP) and $52 \%$ of Brazil's workforce. In Malaysia, SME contributed 37\% on country's GDP, 65\% to current employment and $18 \%$ to exports (Online, 2018). Thus, it is very important to small businesses to know their financial status, such as whether the business is making profit or running at loss. Better financial literacy level among small business owners should lead to better business performance.

\section{Research Background}

Problem Statement

Many perceive that accounting is a very difficult process due to its difficulties and this is very common to small businesses. (Isabel \& Fernandes, 2015) highlights the importance of providing adequate financial education to the small business owner to enhance their performance as business leaders. According to Akhtar \& Liu (2018), accounting literacy is one of the significant factors that influence small business owners to use financial statements in making economic decisions in Pakistan. Study done by Sucuahi (2013) focused on the determinants of financial literacy of micro entrepreneurs. The study is related to the four big topics in financial literacy i.e. record keeping, budgeting, and personal finance and saving. The study found that majority of the respondents in Davao City was still using notebooks and piece of paper in recording their business transactions.

According to Lentz, Smetsers, Vergeer and Grotenhuis (2016), three points of view were defined for looking at financial insight namely, knowledge of financial matters, organizing financial matters and managing and steering the company based on figures. Business owners are confronted with financial problems or other money matters due to entrepreneur does not know enough about money matters or because the financial side of things has been poorly organized and they are struggle with this side of doing business. Almost half (52\%) of 1,676 business owners were not so sure about their knowledge regarding the basic principles of balance sheets and profit and loss accounts.

\section{Purpose of Study}

If a business is unable to keep an adequate accounting record, the operators of businesses will face a major problem (Umeji \& Obi, 2014). Improper book keeping is due to the lack of knowledge in accounting education among the small business owner. If there are no proper maintenance of accounting records, the management itself would not be able to monitor the financial status of the business thus affect the sustainability of the business. Therefore, considering the important roles of small businesses on national economy and little attention of scientific community on recording and reporting, the present study is fulfilling this gap by exploring the level of awareness of having proper accounting records among small businesses in Malaysia. Therefore, this study intended to examine 
INTERNATIONAL JOURNAL OF ACADEMIC RESEARCH IN BUSINESS AND SOCIAL SCIENCES Vol. 8, No. 10, Oct. 2018, E-ISSN: 2222-6990 ㄷ 2018 HRMARS

the extent of accounting literacy which focuses on accounting records of their daily business transactions and financial management among small business owners in Jasin district, Melaka.

\section{Literature Review}

Small and Medium Entities (SMEs)

A definition of small businesses varies within countries and industries (Shaughnessy, 2017). Generally, a business is considered as small based on its number of employees, annual income or type of ownership. For example, in the U.S. business with less than $\$ 10$ million revenue and less than 50 employees is considered as small business (Christie \& Brozovsky, 2010). In addition, the International Accounting Standard Board (IASB) includes small businesses in its definition of smallmedium-entities (SMEs). Small businesses play an important role in strengthening a country's economy (Headd, 2010). Headd (2010) found that small businesses in the United States helped to create two out of three jobs and contributed 39\% of the country's national growth product. In China, 99\% of business entities are small and medium enterprises (Liu, 2012). This shows how important small businesses to a country economy construction.

SMEs in Malaysia

In Malaysia small and medium enterprises are oversee by SME Corporation Malaysia. SME Corporation Malaysia is a Central Coordinating Agency under the Ministry of International Trade and Industry Malaysia that formulates overall policies and strategies SMEs and coordinates the implementation of SME development programs across all related Ministries and Agencies. It acts as the central point of reference for research and data dissemination on SMEs, as well as, provides advisory services for SMEs in Malaysia. SME Corp. Malaysia also assumes the role of the Secretariat to the National SME Development Council (NSDC), which is chaired by the Prime Minister of Malaysia, (www.smecorp.gov.my). Referring to the statistic from Companies Commission of Malaysia (CCM) until June 2018, a total of 7,105,896 businesses were registered in Malaysia. Melaka represent 3.5\% of the total SMEs in Malaysia. Small business in Malaysia can be divided into several sectors include services (89.2\%), manufacturing (5.3\%), construction (4.3\%) agriculture (1.1\%) and mining (1.1\%).

Accounting literacy among SMEs

A recent study of small business owners conducted by Intuit uncovered surprising results. The study found that $40 \%$ of small business owners consider themselves to be financially illiterate. At the same time, $81 \%$ of them are doing their business' finances themselves. If $40 \%$ are financially illiterate, and $81 \%$ are handling their own finances, this means that $32.4 \%$ of those handling their own finances are ill-equipped to do so (Milikowsky, 2017). Although, preparing financial reports is not mandatory for small businesses, they need accounting system to measure business performance and for tax purposes.

This function is usually outsourced to accounting firms. According to accounting regulators, measurement and disclosures are two main issues for accounting practitioners in handling accounting works for small businesses (Christie \& Brozovsky, 2010). Disaggregating personal matters from business finances is another important accounting issue for small businesses (Shaughnessy, 2017). 
Applying loan from commercial bank is considered as the main sources of fund for the small business. Robb et al. (2014) examine the capital structure of small businesses in the first year of their operation and also find a significant use of debt financing as their mainly sources. Study done by Cole (2013) found that small firms tend to concentrate their external borrowing from commercial bank. As the debt financing become the main sources, therefore owner of the business must prepare a set of financial statements to be forwarded to the bank, in order for the bank to make decision whether to approve the loan or not. However, previous studies show that majority of accounting practitioners believe their academic preparation to deal with small business accounting needs and issues is insufficient (Burke, Gandolfi, Training, \& Associates, 2014). With very little helps and guidance for small businesses to record business processes and to managed and preserved these records, studies observed that most small businesses have poor accounting practices. Poor accounting practices leads to financial invisibility, a major obstacle in getting financial aids such as loans and credit facility, especially from banks (Ajibade, Khayundi, \& Africa, 2017).

An accounting literate business owner is more likely to be fully control of their business. Those with poor accounting literature have gained material benefits from simplified accounting training in terms of improved financial practices and quality financial reporting (Drexler, Fischer, \& Schoar, 2010). Accounting literacy is also one of significant factors that influence small business owners to use financial statements in making economic decisions in Pakistan (Akhtar \& Liu, 2018). Gaining an understanding of what Statement of Financial Position and Statement of Profit or Loss mean provides a clear view of financial state of the enterprise and subsequently facilitates smarter business decisions.

Engaging with the basics of accountancy can prepare the owner for a number of the challenges that the business will inevitably encounter. It will allow the business to take advantage of opportunities that arise and increase the business's chances of succeeding. On the other hand, if the owner of the business is accounting illiterate, the business will eventually run into problems, such as allowing expenses to increase to a point where profits are minimal. Although existing studies find many small business owners are relatively satisfied with their business performance, they are not well versed in the basic accounting and financial literacy necessary for long term business success(Dickins, Gibson, Harris, \& Mcdowell, 2016).

\section{Methodology}

Sample and Data Collection

A set of questionnaires was distributed and a total of 51 small business owners from various backgrounds registered with Companies Commissions Malaysia (CCM) responded. The respondents involved in this survey were small businesses located in Jasin district, Merlimau Melaka. Each member of the research team was responsible for distributing questionnaires to members of the sample. This study emphasis on the extent of accounting literacy which focuses on accounting records and financial management among small business owners. 
INTERNATIONAL JOURNAL OF ACADEMIC RESEARCH IN BUSINESS AND SOCIAL SCIENCES

Vol. 8, No. 10, Oct. 2018, E-ISSN: 2222-6990 ㄷ 2018 HRMARS

Development of questionnaires

This study uses questionnaire as a data collection instrument. The design of the questionnaire covered 4 sections. Section 1 was enquired background of the owner or entrepreneur such as gender, age, race, religious, marriage status, business experience and level of education. Meanwhile, for the Section 2 enquired about background of the business, Section 3 is about management of accounting records and Section 4 is about financial management.

A summary of the main sections of questionnaire is shown in table 1 below.

Table 1. Main Section of Questionnaire

\begin{tabular}{|c|c|}
\hline Section 1 & Background of the owner \\
\hline Section 2 & Background of the business \\
\hline Section 3 & Management of accounting records \\
\hline Section 4 & Financial Management \\
\hline
\end{tabular}

A summary of the question items under each section are listed in Table 2.

Table 2. Summary of Question Items

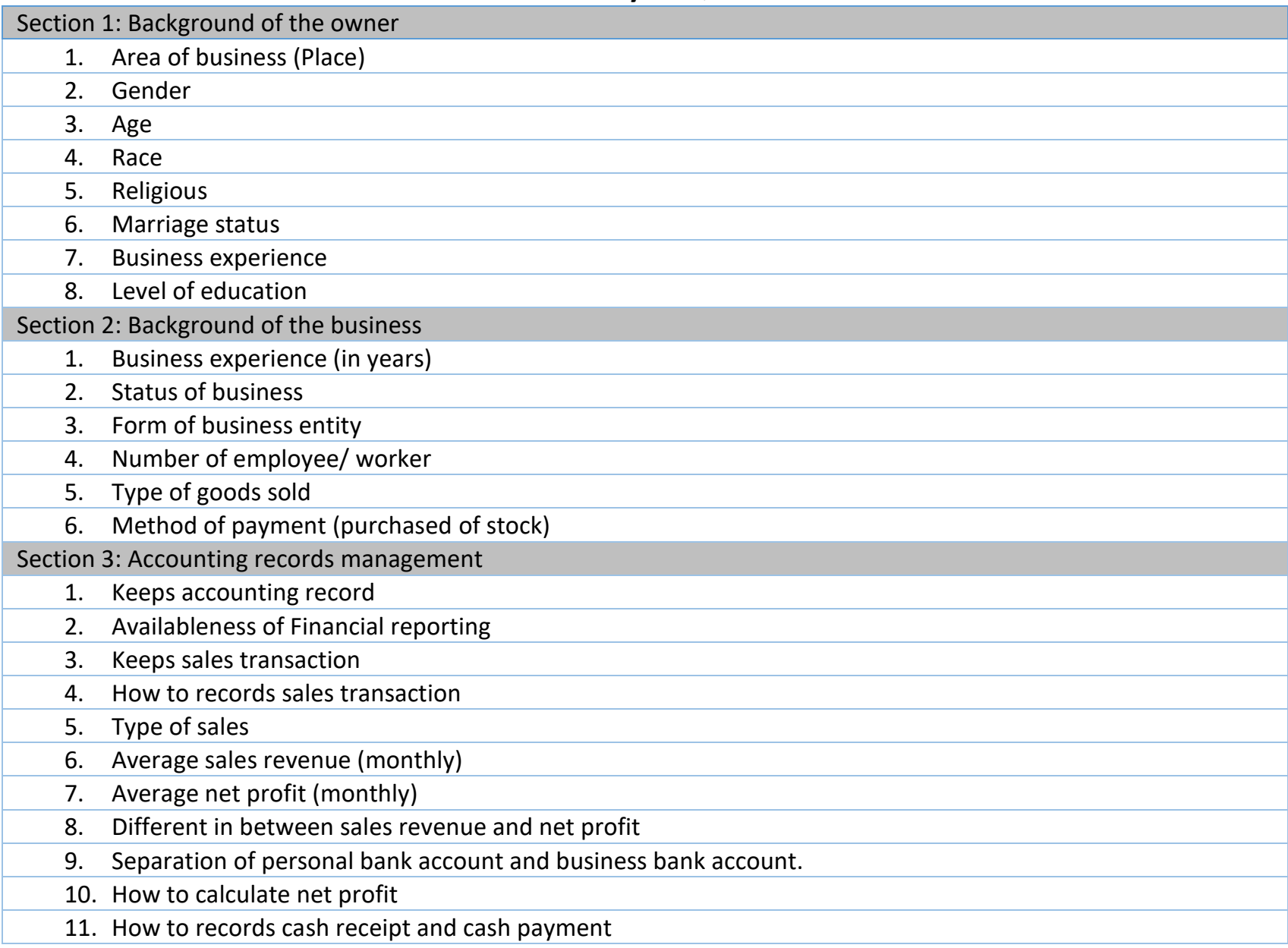


INTERNATIONAL JOURNAL OF ACADEMIC RESEARCH IN BUSINESS AND SOCIAL SCIENCES Vol. 8, No. 10, Oct. 2018, E-ISSN: 2222-6990 @ 2018 HRMARS

Section 4: Financial Management

1. Source of capital

2. Business loan

3. Outstanding payment of loan

4. Effectively in using profit for investment

\section{Results and Discussion}

Demographic Profile

Questionnaires were distributed to Malay-Muslim entrepreneur since they are the majority of the small business owners in 'Jasin' district. A total of 51 business owners responded to the survey. The sampled respondents were required to indicate their gender, age, marital status, business experience and educational background. Out of 51 respondents, $55 \%$ of the entrepreneur were male and the rest were female. All age range were represented in the results which consisted of $18 \%$ under the age of 30 years old, $63 \%$ between 30 to 49 years old and $19 \%$ were 50 years and above. Most of the business owners are married and only $14 \%$ single. In terms of the educational background, $24 \%$ do not finished their school, $39 \%$ got their SPM while others graduated with certificates, STPM and degree. The respondents possessed a wide range of business experience in which $10 \%$ of them have less than 2 years' experience, $28 \%$ with 2-5 years' experience and $62 \%$ with more than 5 years' experience. Although the sample was small, findings from this study provided insights on the accounting literacy among small business owners. Besides analyzing on the background of the business owners, there is also a section in the questionnaires which required the respondent to fill in their business background. From the figure below, results showed that $88 \%$ of the business were sole proprietor and the rest were partnership. Majority (82\%) of the business employed 1-3 workers, $14 \%$ employed 4-8 workers and $4 \%$ employed more than 8 workers. Additionally, $69 \%$ owners run their business full time while the rest do business on a part time basis. $92 \%$ of the business owners use cash basis in running their operation or purchasing transactions meanwhile only $8 \%$ used both cash and credit transactions. This study also showed the types of selling products by the business owners which are garments, food, plant fertilizers, grocery and online business. Almost $60 \%$ if the business owners sell foods as their main income.

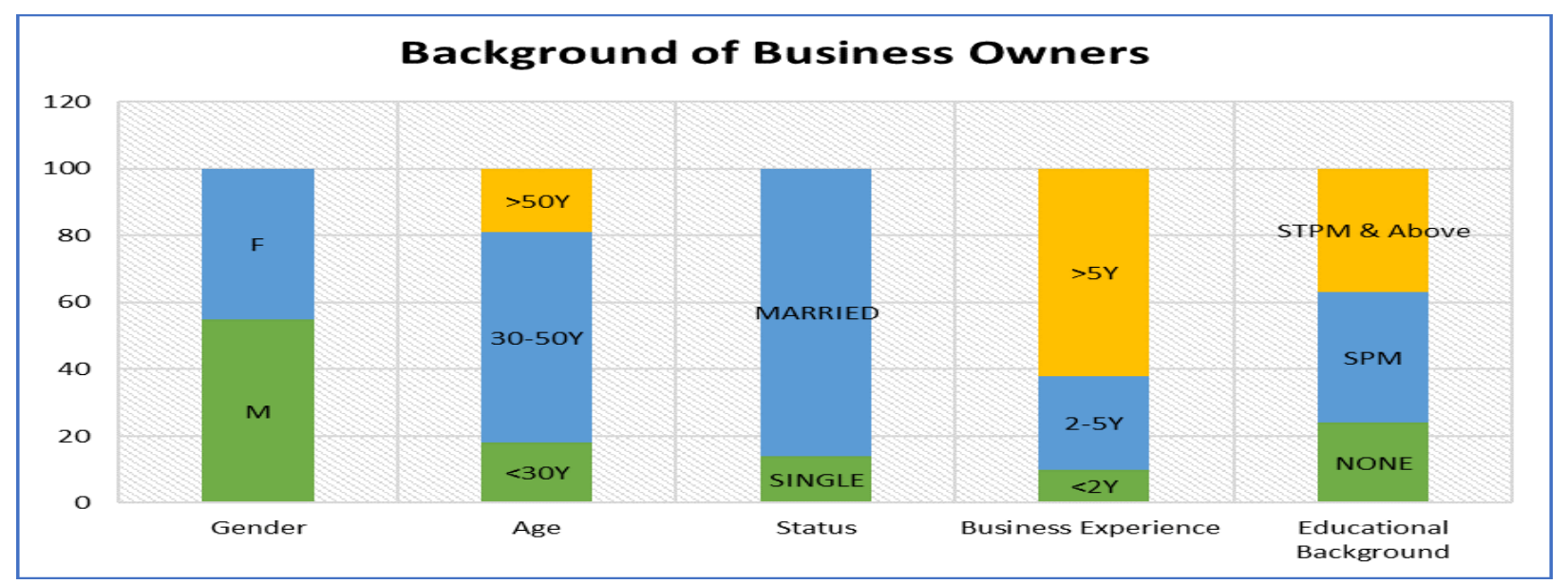


INTERNATIONAL JOURNAL OF ACADEMIC RESEARCH IN BUSINESS AND SOCIAL SCIENCES Vol. 8, No. 10, Oct. 2018, E-ISSN: 2222-6990 @ 2018 HRMARS

Figure 1. Background of Business Owners

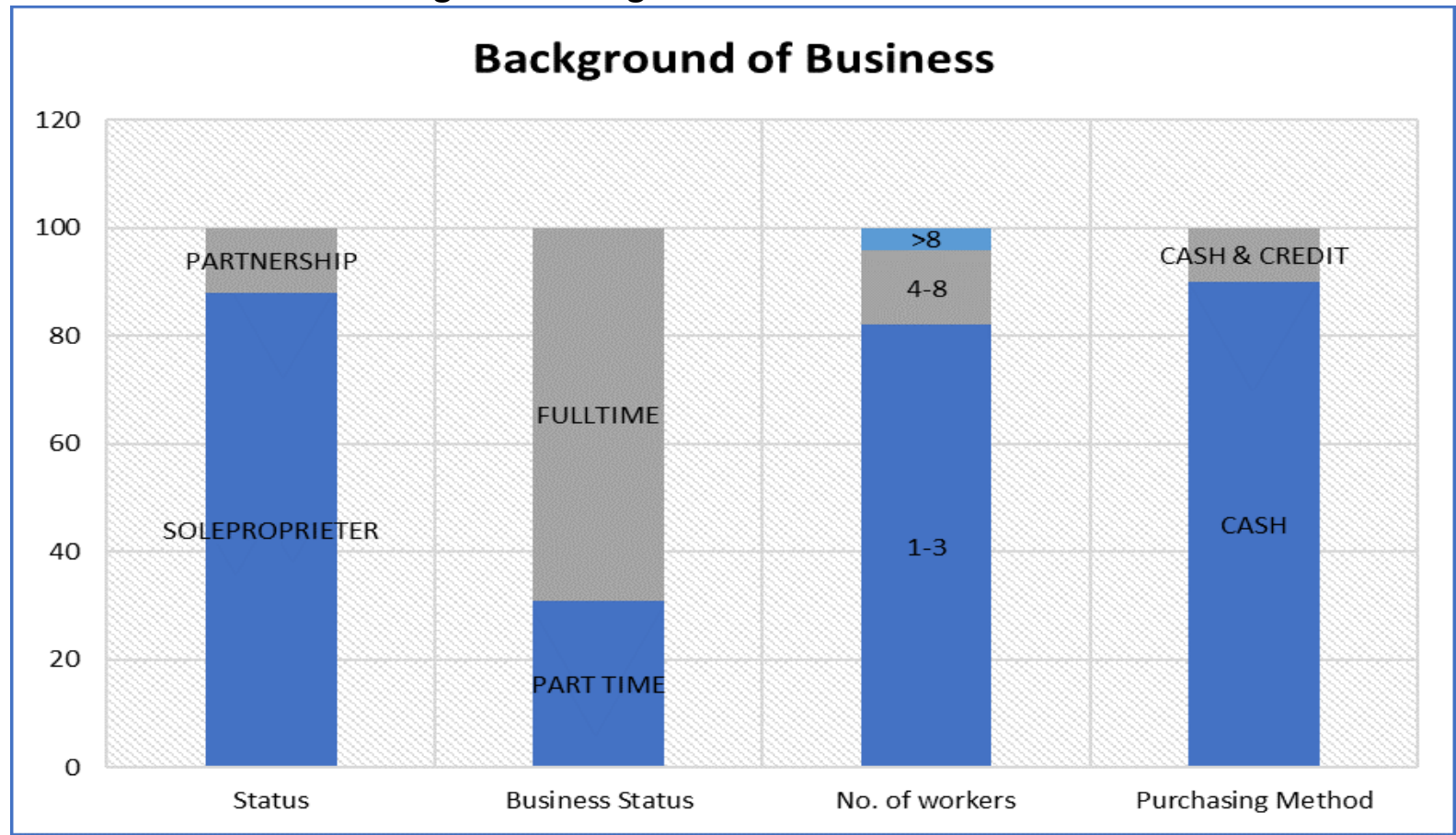

Figure 2. Background of Business

\section{TYPES OF SELLING PRODUCTS}

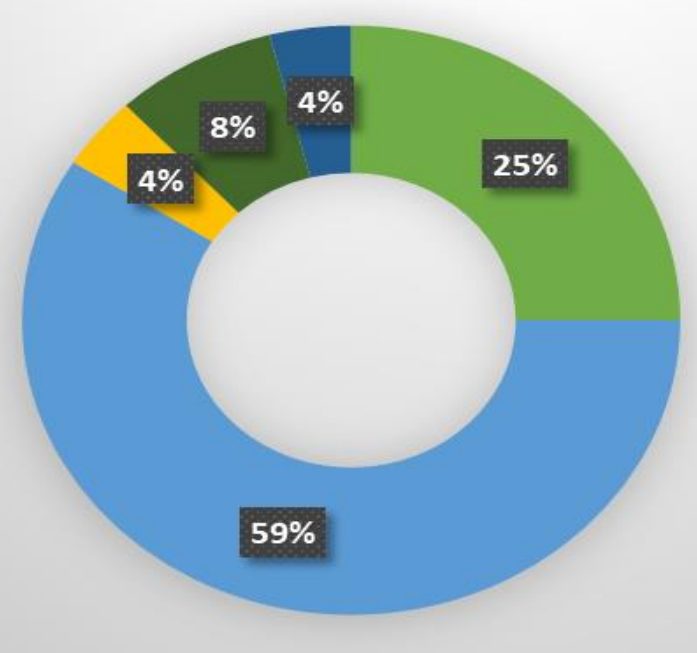

Garments

Food

- Plant Fertilizers

- Groceries

- Online business

Figure 3. Types of Selling Products 
INTERNATIONAL JOURNAL OF ACADEMIC RESEARCH IN BUSINESS AND SOCIAL SCIENCES Vol. 8, No. 10, Oct. 2018, E-ISSN: 2222-6990 @ 2018 HRMARS

\section{Records Management}

Documentation

The survey conducted showed that $92 \%$ businesses carried out their operation on cash basis while the remaining $8 \%$ businesses operation were based on cash and credit basis. Furthermore, as shown in Figure 4 , only $39 \%$ of the businesses kept all the documents related to the business for future references while $61 \%$ of them did not have proper record keeping for all the business documents. This indicated that small businesses did not have proper record keeping of the business documents due to cash basis operation. Apart from that, it is important for the small businesses to have a separate business bank account from the personal bank account in order to ease the process of tracing business transactions. The separation between business and personal transactions is required by the accounting concept under business entity concept (Abd Rauf, Abu \& Mahmud, 2017). From this survey, $47 \%$ of the businesses have a separate business bank account from the personal bank account while $53 \%$ of the businesses' owners used their personal bank account for business activities.

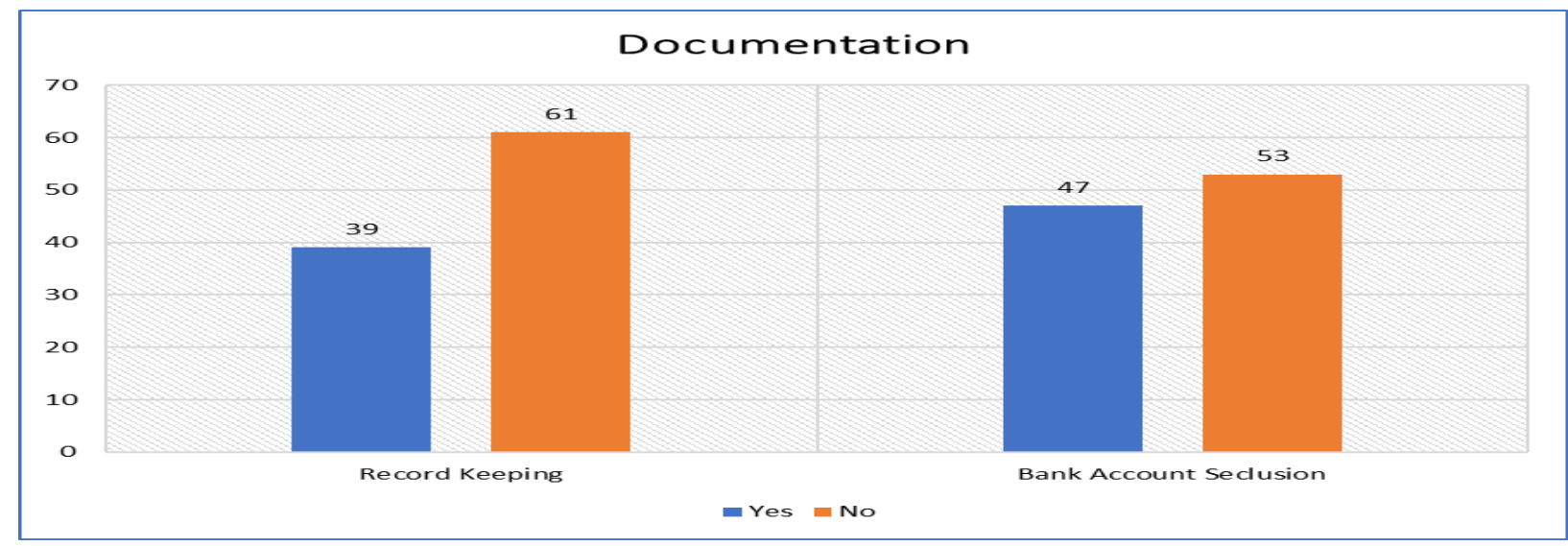

Figure 4. Documentation

\section{Revenue and Net Profit}

The survey conducted revealed that $41 \%$ of the businesses recorded less than RM3,000 of their average monthly sales, meanwhile $31 \%$ of the businesses recorded average monthly sales of RM3,000 to RM5,000 and the balance $28 \%$ businesses recorded average monthly sales of more than RM5,000. From the recorded average monthly sales, the businesses were able to identify their average monthly net profit generated. Figure 6 shows that 37\% businesses recorded less than RM1,000 of average monthly net profit, $37 \%$ businesses also generated average net profit of RM1,000 to RM3,000 and the balance $26 \%$ businesses generated more than RM3,000 of average monthly net profit.

It is essential for the businesses to distinguish between sales and net profit generated from the business activities. Besides having knowledge on this differences, it is also important to know the basis on how the businesses calculate their net profit for the business in order to help the owner to know the current financial position of their business. From the result obtained, $67 \%$ of the businesses knew how to calculate the correct net profit, namely by deducting purchasing cost and other expenses from the total sales. Besides, $22 \%$ businesses calculated net profit by deducting purchasing cost only from the total sales. However, $8 \%$ of the businesses assumed that net profit is equal to net 
INTERNATIONAL JOURNAL OF ACADEMIC RESEARCH IN BUSINESS AND SOCIAL SCIENCES Vol. 8, No. 10, Oct. 2018, E-ISSN: 2222-6990 @ 2018 HRMARS

profit and another 3\% businesses anticipated net profit is equal to total of cash in hand and cash at bank.

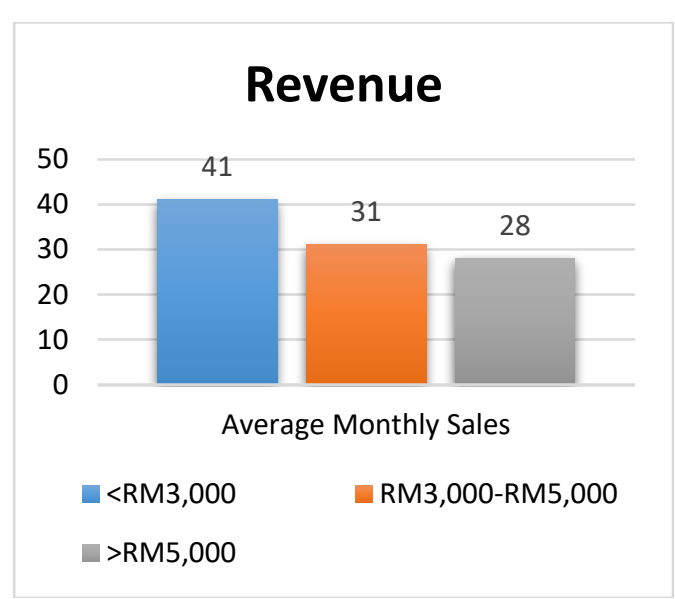

Figure 5. Revenue

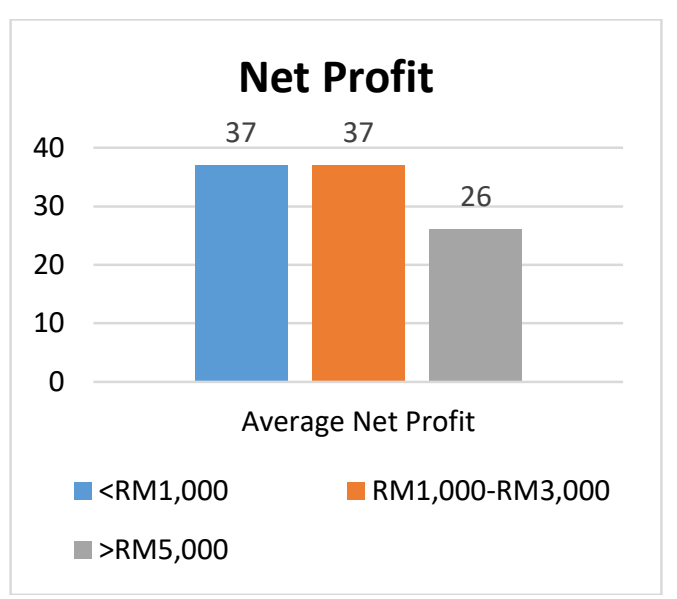

Figure 6. Net Profit

\section{Business Transactions and Financial Reports}

Further investigation has been conducted regarding the recording of the sales transaction. The result indicated that $55 \%$ of the businesses recorded all the sales transactions whereas $45 \%$ of the businesses did not have a proper record for all the sales transactions. Moreover, $45 \%$ of the businesses manually recorded all the sales transactions using note book, $8 \%$ of the businesses recorded using gadget either hand phone, tablet or iPad, $6 \%$ of the businesses issued official receipts as their as their references for record keeping and the remaining $41 \%$ did not have any record keeping for all the sales transactions. Besides, the recording of the cash receipts and business operating expenses are equally important with sales transaction as majority of the small businesses under investigation run operation based on cash basis transactions. 53\% of the businesses used note book to record the cash receipts and business operating expenses, while $12 \%$ of the businesses used retail cash book. However, $35 \%$ of the businesses were not making any records of the cash receipts and business operating expenses.

Above all, the preparation of financial reports for the businesses is undeniable very important in determining the business performance and financial position. The owner of the business would be able to identify any weaknesses of the business and subsequently able to take the appropriate actions to improve the overall financial position. This could ultimately sustain the operation of the business for a long time. From the result obtained in Table 4, only 33\% of the businesses prepared business financial reports, whereas $67 \%$ of the businesses did not prepare any financial reports for the business. 
INTERNATIONAL JOURNAL OF ACADEMIC RESEARCH IN BUSINESS AND SOCIAL SCIENCES Vol. 8, No. 10, Oct. 2018, E-ISSN: 2222-6990 @ 2018 HRMARS

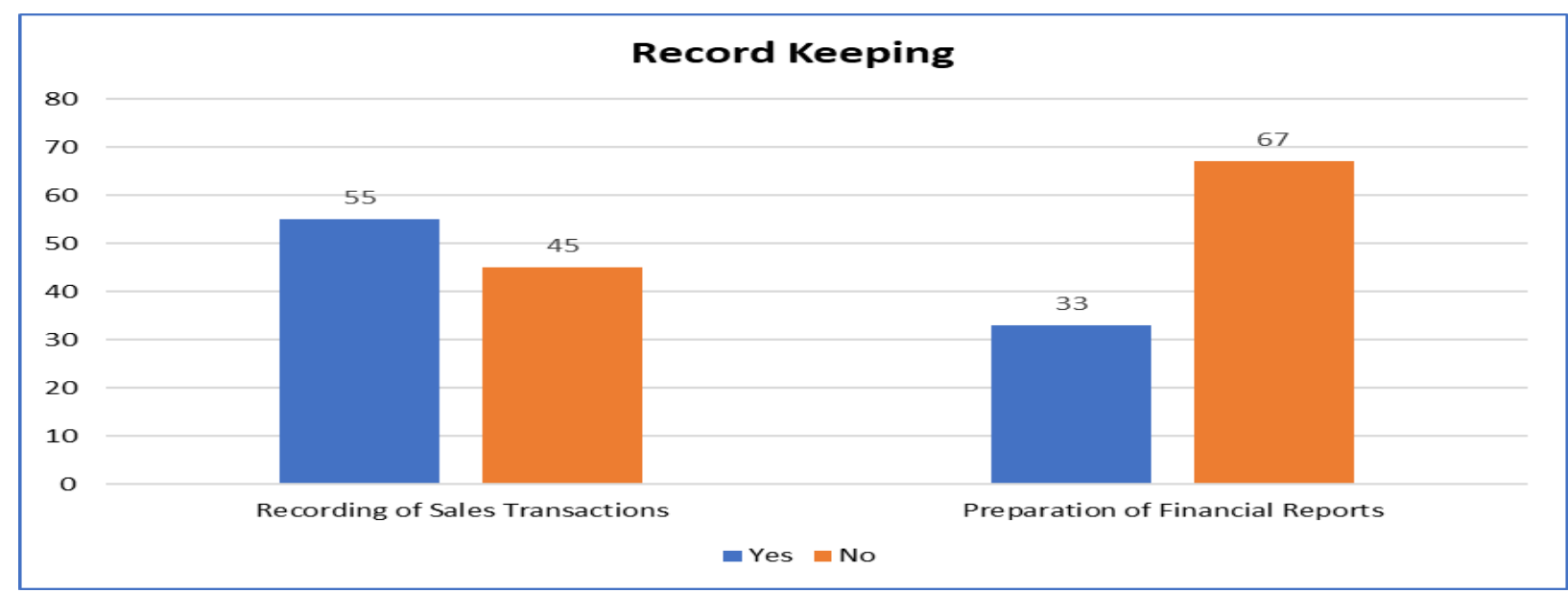

Figure 7. Record Keeping

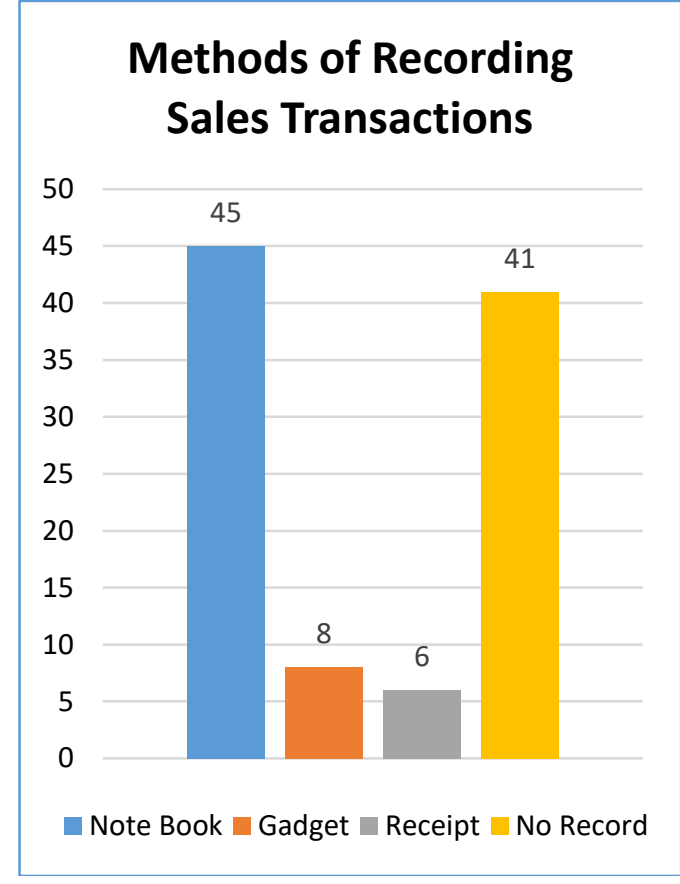

Figure 8. Sales Recording Method

\section{Methods of Recording Cash Receipts and Business Operating Expenses}

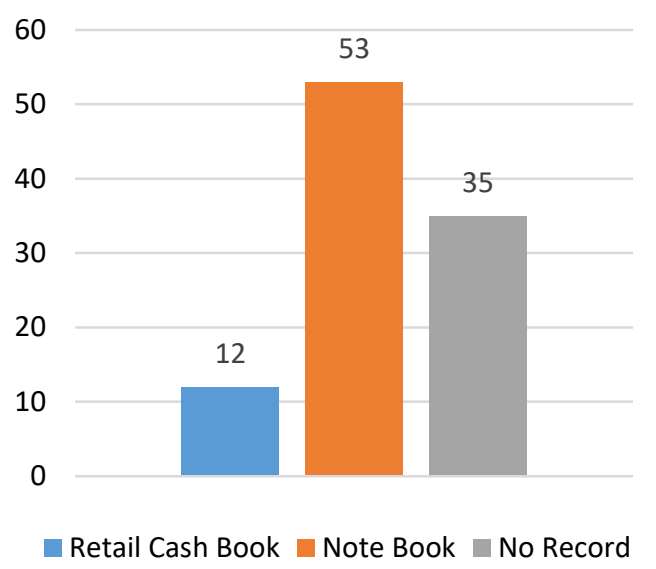

Figure 9. Receipts \& Expenses Recording Method

Financial Management

The survey revealed that $80 \%$ of the small business owners started business either by using their own money or with the help of family and friends. Meanwhile, only $20 \%$ of them get their capital from loan financing. For owners taking loan financing, most of them get help from Amanah Ikhtiar Malaysia (60\%), Agro Bank (10\%) and Bank Rakyat (30\%). The loan amount varies in range from RM3,000 up to more than RM50,000 with loan tenure of $1-2$ years (60\%) and more than 5 years (40\%). Results indicate that most of the small business owners are comfortable of self-financing rather than approaching other financing sources. This might be due to the difficulties in getting loan since application requires documentation and collateral, meanwhile small business owners are not required to keep a proper business records. 
Financial management is essential for a business to sustain in a long period of time. The management of business activities, cash flows and profit will give big impact on performance of the business. As the business grows and matures, it will require more cash to finance its operation. It means that, owners must gain more money by making financial projections or arrange the profit for future investment. However, very less of the respondent use their profit for investment. Only $37 \%$ of them invest their business profit in order to gain more income that can be used for their business expansion.

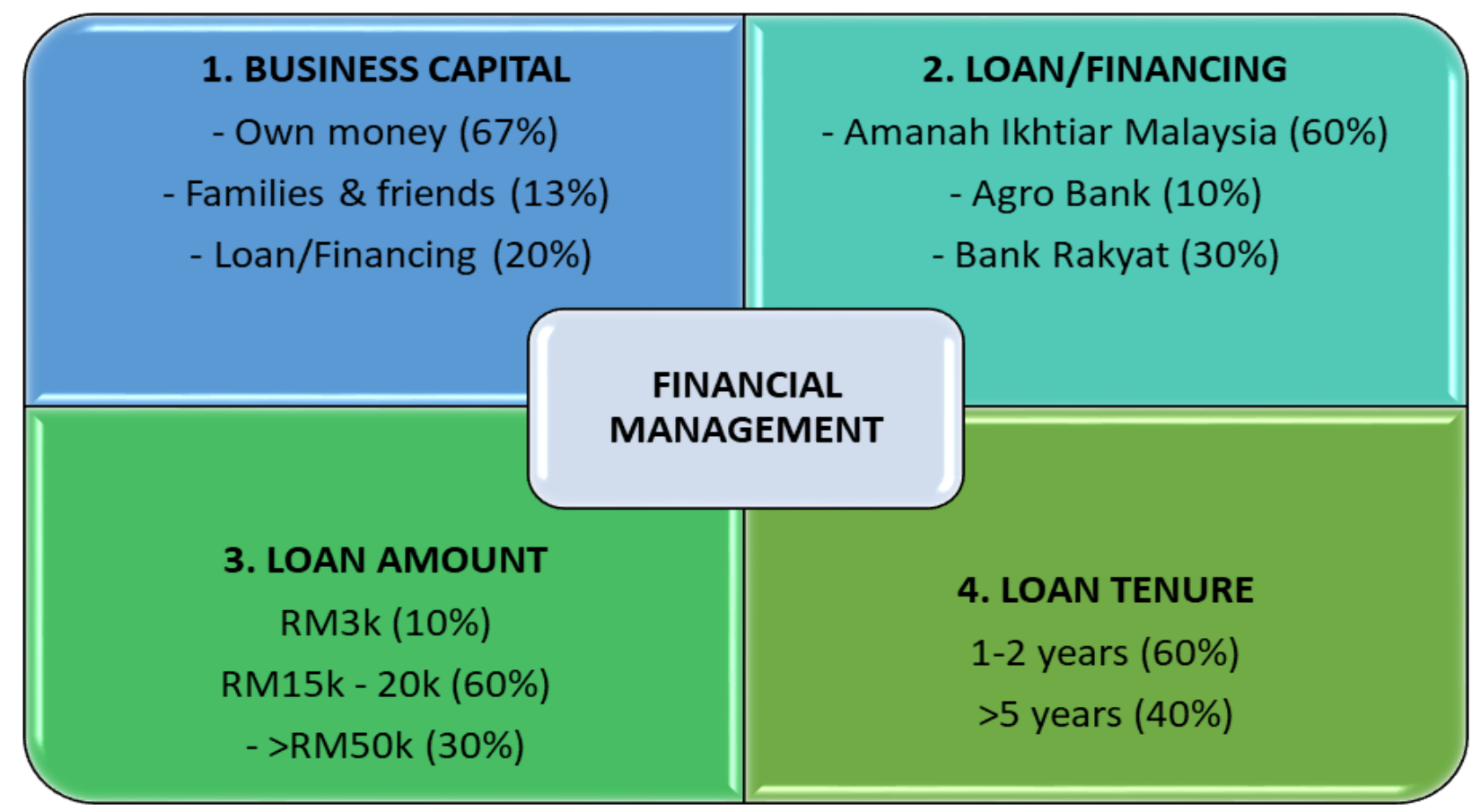

\section{Conclusion}

Figure 10. Financial Management

This study examined on accounting literacy among small business owners in Jasin district, Merlimau Melaka. The study focuses on accounting records and financial management. Findings showed that accounting literacy are still very weak among the small business owners in Jasin district. In terms of documentation, majority of the sampled SMEs do not have proper record keeping and do not concern on separation of business and personal transactions. Most of them are still recording daily transactions manually. In additions, there are owners who do not know the differences between revenue and net profit. As expected, almost $70 \%$ of them did not maintain any financial reports for the business. In terms of financial management, most of the owners use self-financing in running their business. This is because they are reluctant to take risk of not paying the loan commitment. Since small business owners are not required to keep a proper business record, it might be difficult for them to apply for loan financing.

These results indicate small business owners are still unaware with the essential of accounting literacy which could provide great opportunities for them to grow and sustain in a long period of 
time. Taking into accounts the characteristics of small business in Malaysia, it is important to assist and facilitate SMEs in records and financial management. Therefore, the analysis on the accounting literacy among SMEs in Malaysia is essential to support in the development of the SMEs industry. It is suggested that regulatory bodies promote a specific reporting guideline tailored made for the small businesses. Besides, the introduction of a simple and less complex reporting template should be establish in assisting the owners in reporting their financial status. Monetary and moral support from local authorities is also essential in improving the level of awareness among small businesses in reporting and managing their financial transactions. The findings from this study might not be generalized since it is based on a limited number of respondents.

\section{Corresponding Author}

Nurfarahin Roslan, Faculty of Accountancy, Universiti Teknologi MARA, Melaka, Malaysia.

UiTM Cawangan Melaka, Kampus Jasin, Merlimau.

Email: nurfarahin126@melaka.uitm.edu.my 
INTERNATIONAL JOURNAL OF ACADEMIC RESEARCH IN BUSINESS AND SOCIAL SCIENCES

Vol. 8, No. 10, Oct. 2018, E-ISSN: 2222-6990 ㄷ 2018 HRMARS

\section{References}

Ajibade, P., Khayundi, F. E., \& Africa, S. (2017). The Role of Records Management in Small Micro and Medium Enterprises (SMMEs) in South Africa and Its Implications for Business Sustainability, 27(2), 175-188.

Akhtar, S., \& Liu, Y. (2018). SMEs' use of financial statements for decision making: Evidence from Pakistan. Journal of Applied Business Research, 34(2), 381-392. http://doi.org/10.19030/jabr.v34i2.10138

Burke, M. M., Gandolfi, W. R., Training, S., \& Associates, C. (2014). U.S. Accounting Education: Misalignment with The Needs of Small and Medium Companies, 7(4), 339-349.

Christie, B. N., \& Brozovsky, J. (2010). Accounting for Small Businesses: The Role of IFRS, (JULY), 4044.

Coda, R., Viveiros, P., Krakauer, D. C., \& Franc, D. De. (2018). Are small business owners entrepreneurs? Exploring small business manager behavioral profiles in the São Paulo Metropolitan region, 53, 152-163.

Cole, R. A. (2013). What Do We Know about the Capital Structure of Privately Held US Firms? Evidence from the Surveys of Small Business Finance. Financial Management.

Cole, R., \& Sokolyk, T. (2016). Who needs credit and who gets credit? Evidence from the surveys of small business finances $\leftleftarrows$. Journal of Financial Stability, 24(March 2014), 40-60.

Companies Commissioner of Malaysia (2018). http://www.ssm.com.my/en/statistic-total businesscompanies?

Dahmen, P., \& Rodríguez, E. (2014). Financial Literacy and the Success of Small Businesses: An Observation from a Small Business Development Center Financial Literacy and the Success of Small Businesses: An Observation, 7(1).

Dai, N., Ivanov, V., \& Cole, R. A. (2017). Entrepreneurial optimism, credit availability, and cost of financing: Evidence from U. S. small businesses. Journal of Corporate Finance, 44, 289-307.

Dickins, D., Gibson, S. G., Harris, M. L., \& Mcdowell, W. C. (2016). Financial Literacy in Family Firms for Business Owners and Student Learning, 21(3), 57-73.

Drexler, A., Fischer, G., \& Schoar, A. (2010). Keeping it simple : Financial Literacy and Rules of Thumb Keeping it Simple: Financial Literacy and Rules of Thumb. CEPR Development Economics 
INTERNATIONAL JOURNAL OF ACADEMIC RESEARCH IN BUSINESS AND SOCIAL SCIENCES

Vol. 8, No. 10, Oct. 2018, E-ISSN: 2222-6990 ㄷ 2018 HRMARS

Workshop, 6(October), 8-9. http://doi.org/10.1257/app.6.2.1

Durguner, S. (2017). Journal of International Financial Markets, Institutions \& Money Do borrowerlender relationships still matter for small business loans? Journal of International Financial Markets, Institutions \& Money, 50, 98-118.

Headd, B. (2010). An Analysis of Small Business and Jobs, (March).

Isabel, T., \& Fernandes, M. (2015). “Financial Literacy Levels of Small Businesses Owners and it Correlation with Firms' Operating Performance" by Master in Finance Dissertation.

Kurniawati, E. P., Kurniawan, E. Y., \& Kristiani, M. (2013). Accounting Information for Business Decision Making and Performance Assessment in Small and Medium Enterprises (SMEs). The Journal of Social Science.

Lentz, M., Smetsers, D., Vergeer, E. and Grotenhuis, M. (2016). In Control of the Company: Entrepreneurs on their Financial Literacy, Netherlands Chamber of Commerce. www.kvk.nl/onderzoekgeldzaken

Liu, Z. (2012). Management \& Engineering The Construction of SME Accounting Information System, 07, 31-35. http://doi.org/10.5503/J.ME.2012.07.004

Milikowsky, J. (2017). The Truth About Financial Literacy and Small Business Owners.

Robb, A. M., Robinson, D. T., Robb Uc, A. M., Cruz, S., \& Robinson, D. (2014). The Capital Structure Decisions of New Firms. Source: The Review of Financial Studies.

Said, J., Hui, W., Othman, R. \& Taylor, D. (2010). The mediating effects of organizational learning orientation on the relationship between strategic management accounting information use and organizational performance. Asia-Pacific Management Accounting Journal, 5(2), 11-29.

Shaughnessy, D. O. (2017). Introduction of accounting practices in small family businesses, 14(2), 111-136. http://doi.org/10.1108/QRAM-01-2015-0008

Sucuahi, W.T. (2013). Determinants of financial literacy of micro entrepreneurs in Davao City. International Journal of Accounting Research, 1(1), 44-51.

Umeji, A. U., \& Obi, C. A. (2014). Cost Accounting Skills Needs of Small Business Operators. American Journal of Industrial and Business Management, 4(5), 246-257.

Abd Rauf, F., Abu, A. \& Mahmud, R. (2017). Financial Accounting for Non-Accounting Students-Fifth Edition, Mc Graw Hill Education. 
INTERNATIONAL JOURNAL OF ACADEMIC RESEARCH IN BUSINESS AND SOCIAL SCIENCES Vol. 8, No. 10, Oct. 2018, E-ISSN: 2222-6990 @ 2018 HRMARS

Online, S. (2018). Malaysia's SME GDP contribution to exceed $40 \%$, pp. 1-5. Retrieved from https://www.thestar.com.my/business/business-news/2017/07/13/malaysias-sme-gdpcontribution-to-exceed-40pct/ 